\title{
PUNITIVISMO E⿱ PARTICULARISMO NO OCASO PÓSMODERNO
}

\author{
Punitivism AND PARTICULARISM ON THE \\ POST-MODERN DECLINE
}

\section{Punitivismo y particularismo EN El DeClive POSMODERNO}

Paulo Ferreira da Cunha

1 Sinais dos tempos. 2 Direito, civilização e mudança. 3 Perigo do punitivismo politicamente correto. 4 No fio da navalha. 5 Prospetiva. Referências.

"[...] sondern neue Vorurteile werden, eben sowohl als die alten, zum Leitbande des gedankenlosen großen Haufens dienen.”

Kant, Was ist Aufklaerung?, 1784.

\begin{abstract}
"A função da lei é a de nos proteger contra a fraude de outrem; mas não a de nos dispensar do uso da nossa própria razão. Já de outro modo, a vida dos homens, sob a violência das leis, não seria mais do que uma longa e vergonhosa necessidade; e esta vigilância, ela própria, degeneraria em inquisição.” (PORTALIS apud CORREIA, 1985, p. 11).
\end{abstract}

\section{RESUMO}

O presente artigo chama a atenção para a necessidade de o Direito manter a sua vocação universalista, por meio de comandos que classicamente eram tidos por gerais e abstratos. Esse universalismo sublinha que, sem prejuízo da Equidade, a Lei é igual para todos. Contra essa visão geral, que se poderia considerar de inspiração clássica, cristã, humanista, iluminista,

* Juiz Conselheiro do Supremo Tribunal de Justiça (Portugal), Professor Catedrático da Faculdade de Direito da Universidade do Porto (em licença para o exercício da magistratura). Faculdade de Direito da Universidade do Porto, (FDUP) - Porto, Portugal. E-mail: <lusofilias@gmail.com>. http://orcid.org/0000-0002-3602-8502 
veteroliberal (o contrário de neoliberal), democrática e social (ou seja, com a mesma origem do Estado Constitucional), têm surgido formas de autarcia legal, particularismos, certos comunitarismos, defesa de grupos especiais, por um lado, e, por outro, tentativas de imposição, mesmo pela força da criminalização, de certas (e normalmente até minoritárias) visões do mundo, da vida, dos costumes. Se outrora se ganhou ao abolir a carga moralista do Direito, assim como foi de saudar o processo da sua laicização, de novo faz sentido uma análise crítica das propostas de mudança de vida por via da Lei, que podem ser totalitárias.

Palavras-chave: Particularismo. Punitivismo. Totalitarismo. Utopia.

\begin{abstract}
This article draws the attention to the need to maintain Law's universalist vocation, through commands that were classically considered being general and abstract. This universalism stresses that, without prejudice to Equity, the law is the same for everyone. Against this overview, which could be considered classical, Christian, humanist, Enlightened, old liberal (the opposite of neoliberal), democratic and social (i.e. with the same origin as the Constitutional State), new forms of legal isolationism, particularisms, certain communitarianism, defense of special groups, on the one hand, and, on the other hand, attempts to impose, even by the force of criminalization, of certain (and usually even minority) visions of the world, of life, of customs. If once society gained by abolishing the moralistic burden of law, as well as welcoming the process of its secularization, again it's time to promote a critical analysis of the proposals for life change by law, which can be totalitarian.
\end{abstract}

Keywords: Particularism. Punitivism. Totalitarianism. Utopia.

\title{
RESUMEN
}

Este artículo llama la atención sobre la necesidad de que la Ley mantenga su vocación universalista, por medio de comandos que clásicamente se consideraban generales y abstractos. Este universalismo subraya que, sin perjuicio de la Equidad, la Ley es la misma para todos. Frente a esta visión general, que podría considerarse clásica, cristiana, humanista, ilustrada, veteroliberal (en oposición a neoliberal), democrática y social (es decir, con el mismo origen que el Estado Constitucional), han surgido formas de autonomía legal, particularismos, ciertos comunitarismos, defensa de grupos especiales, por un lado, y, por otro, intentos de imponer, incluso por la fuerza de la criminalización, ciertas (y generalmente incluso minoritarias) visiones del mundo, de la vida, de las costumbres. Si alguna vez se ganó aboliendo la carga moralista de la Ley, al igual que para dar la bienvenida al proceso de secularización, nuevamente tiene sentido analizar críticamente las propuestas que cambian la vida a través de la Ley, que puede ser totalitaria.

Palabras Clave: Particularismo. Punitivismo. Totalitarismo. Utopía. 


\section{SINAIS DOS TEMPOS}

Tanto os pós-modernos teóricos apregoaram o fim das metanarrativas ${ }^{1}$ e, com elas, da esperança e dos sonhos sociais e políticos (tudo isso restringindo assim a egoísmos e a aspirações pessoais - no máximo, doiradas de uma "legitimação" pseudo-"meritocrática"), que acabamos por ter hoje um mundo desencantado ${ }^{2}$, em grande medida sem sentido e sem direção. A incapacidade de gerir em conjunto desafios à nossa Casa Comum, efetivamente não ideológicos (ou não classicamente ideológicos), como a causa climática, por cujo desprezo todos sofreremos, não se enquadra nas preocupações de Portalis, citadas por Eduardo Correia, relativamente à necessidade de alguma abstenção penal com as questões do âmbito económico (CORREIA et al., 1985, p. 9). Existem casos em que, pelo contrário, há um imperativo de intervenção. Nomeadamente, no tema referido, porque se trata da sobrevivência da Humanidade no Planeta.

No entanto, não há dúvida de que os temores de Portalis contra o inquisitorialismo eram justificados, embora noutro contexto. Por vezes, surgem causas muito localizadas (particularistas), ora até bizarras, ora simplesmente laterais, ora potencialmente totalitárias, por interferirem com liberdade legítima de outros, querendo impor-lhes ideias e comportamentos muito para além do admissível em uma sociedade pluralista e chocando quer com a Liberdade em geral, quer com Direitos Humanos e Fundamentais. Desde logo, o direito à tradição e às tradições ${ }^{3}$, que não é direito absoluto, obviamente (não valem tradições contra Direitos Humanos, por exemplo), mas tende a ser totalmente olvidado.

Na vozearia, na desconexão, na pulverização que nos chega pela comunicação social (incluindo redes sociais, naturalmente) omnipresente e todo-poderosa (impondo o consumo de produtos, serviços e candidatos ao poder, apesar de tudo felizmente ainda eletivo), não se divisa, paradoxalmente, que haja um sentido, um rumo, uma estratégia de fundo para o nosso tempo. Que fossem várias e até opostas! Uma boa navegação de cabotagem, com resultados imediatos menos maus, já seria de aplaudir. Mesmo os pretensos afirmativos e pró-ditatoriais têm uma intenção consabida: consolidar a anarquia da lei do mais forte, uma espécie de retorno ao estado de natureza. Não é um programa político, mas a negação do político. Por isso, sem se darem conta da sua ideologia, tanto pregam contra a ideologia ("dos outros" - heterodoxy is another man's doxy), os quais, contudo, são cada vez menos ideológicos, ou autonomamente ideológicos, conformando-se frequentemente com uma versão talvez moderada do mesmo status naturalis.

Entretanto, quando atentamos, por exemplo, para o repetido testemunho do filósofo Luc Ferry, que foi membro do governo francês, começamos a ter a confirmação da suspeita: teremos de dizer, com um sorriso amarelo nos lábios, que o lema do liberalismo clássico realmente

1 Por todos, o já clássico Lyotard (1989), La Condition postmoderne; matizando um tanto o que viria a ser vulgarmente considerado como pós-modernidade, nomeadamente no seu diálogo com a modernidade, Lyotard (19 , p. 202).

2 Cf., desde logo, Gauc-het (1985).

3 Uma visão mais integrada que as habituais é a de Puy (1985), não deixando de assinalar alguns direitos pouco ou nada falados, com dimensão cultural e histórica, de raiz e alguns raramente referidos (medicação, celibato, lar, amor, tradição, progresso, inatividade, ócio, etc.). Também na sua Tópica se assinalam locii como direito mítico, natural, histórico, originário (mas também obsoleto e evoluído), consuetudinário, etc. V. (PUY, 1984, passim). 
triunfou - le monde va de lui même. Tanto se deu largas ao laissez passer, que a nossa civilização parece estar à deriva, e (parece sugeri-lo o ex-governante Luc Ferry) nem os governantes dela têm as rédeas ${ }^{4}$. Por isso, é tão pungente (mas com algo de ridículo) ver pessoas injustiçadas, ou que o julgam ser, bradarem contra os governos (quaisquer uns), apontando-os a dedo, acreditando que os governos são os culpados, quando a solução muito frequentemente por eles não passa. Evidentemente que os governos ainda decidem muita coisa e podem fazer muito (sobretudo podem fazer muito mal, se quiserem - e, em certos casos fazem-no mesmo, e com plena consciência disso), mas não detêm os lemes da História, nem de perto nem de longe. Não há, assim, quem se preocupe com os rumos que a inteligência, as mentalidades estão a tomar, rumos decorrentes de um paralelogramo de forças desconexas, naturalmente. Nem se pense que, na atual situação de burocratização extrema e de dependência dos mercados, ao menos e in extremis as instituições académicas poderiam (ao menos elas) dedicar-se a pensar. Não têm tempo para fazer os múltiplos relatórios e as estatísticas com que são ocupadas repetidamente. E diria uma teoria da conspiração, contudo bastante plausível: "para que se não ocupem de coisas importantes" e não façam política. Aliás, a obsessão de alguns políticos com a política supostamente feita por professores é prova de que os professores com tempo e sentido crítico (duas coisas que a burocracia reduz tragicamente) são um perigo... Não vá eles recomeçarem a pensar! E a pensar para além de consabidos esquemas, aplicações mecânicas e silogísticas.

O pensar no estrito domínio de uma especialidade é muito restritivo. Por isso, na novela póstuma de Herman Melville Billy Budd (que tem adaptação em ópera e em cinema, aliás), Vere, comandante do Bellipotent, no conselho de guerra que iria julgar o marinheiro a bordo do navio, não via prudentes julgadores, embora todos os juízes ad hoc tivessem conhecimentos profundos em assuntos de navegação. É o problema dos especialistas profissionais a julgar coisas para que se necessita experiência de vida... e do Direito.

Um dia poderá ser tarde para reconhecer (e disso tirar as devidas consequências práticas) que o uso da lógica formal ou de belos paradoxos pseudo-inteligentes não resolve (pelo contrário) coisas concretas. Que são coisas concretas? Essas coisas simples (mas complexas, se vistas em profundidade) do quotidiano normal das pessoas normais, que são, em geral, grandes consumidores (mentais e materiais) de invenções e descobertas de elites (não de oligarquias $)^{5}$ e que vivem na imitação de metas e comportamentos que outros apontam, como bem advertiu já Tarde (1976).

A Pessoa não é um silogismo, um algoritmo, um axioma de que baste retirar consequências lógicas, algumas com sérias implicações. Creem alguns que isso é ser inteligente e que os demais são bárbaros. É o contrário que ocorre, na verdade.

Em Direito, então, esse uso de abstrações e a sua aplicação prática é desastroso. Quando então se vai pela sancionação de certas condutas em homenagem ao politicamente correto ${ }^{6}$,

4 V. o início de Ferry e Capelier (2014), e já en passant em Ferry (2006).

5 Cf., v.g., Giannetti (2003).

6 Há quem, de boa-fé, negue a sua existência, mas "confundindo-o" com coisas excelentes como os Direitos Huma- 
e no limite envolvendo a sua criminalização, é deveras preocupante.

O Estado constitucional ${ }^{7}$, estado de direito democrático, social, de cultura e ecologia, grande patamar civilizacional que alcançámos, tem uma matriz não apenas de pluralismo político (partidário, sindical, etc.), mas de pluralismo cultural e de vivências, que implica uma liberdade civil, quotidiana, vivencial, que passa, no seu círculo mais óbvio e mínimo, por cada um ter as convicções (políticas, filosóficas, religiosas...) que tiver, os afetos que desejar, se vestir (ou pentear) como entende (atenta uma adequação social mínima, que não será certamente a mesma em uma praia ou em um templo), comer o que entende, falar como lhe aprouver (apenas com o risco de sanções de trato ou etiqueta social), etc.. Evidentemente que há exageros dessa liberdade: não pode alguém com o seu comportamento pôr em risco a sociedade: conduzindo perigosamente, não se vacinando nem aos filhos, recusando a educação, usando armas sem licença em nome da sua defesa própria e assim transformando a sociedade no Faroeste e pondo em risco a própria vida e a dos outros, na maior parte dos casos em que não seja pistoleiro - como a maioria não é.

Colocar em causa a disponibilidade pessoal sobre esses grandes códigos sociais, subordinando-os primeiro a um "inquisitorialismo" 8 social de verdadeiro "assédio social" contra os que não sigam um padrão de um determinado grupo (e pode haver grupos conflituantes), e, depois, ganha a batalha do terrorismo social (mediático e político), impondo legislativamente condutas obrigatórias relativamente a tais códigos, é uma mudança qualitativa na qualidade do ar que se respira.

Passa-se de um ar livre, pluralista, para um hálito de bafio ditatorial, que, precisamente por atacar a liberdade mais elementar das pessoas (independentemente das grandiloquentes justificações com que tal opressão se possa doirar), ganha contornos de totalitarismo, e não apenas de autoritarismo, o qual, frequentemente, deixaria ainda (ao contrário do primeiro) algum espaço de movimentos a uma vida privada pacata e tradicional. Aliás, um dos elementos de totalitarismo é o romper com tradições enraizadas (por exemplo, a forma normal de comer, em uma dada sociedade, e sobretudo a maneira secular de falar). Pode haver tradições repugnantes e até criminosas, em um sentido prudente e forte do termo (que implicam tortura, humilhação, mutilação, segregação de outros seres). Mas não se trata dessas tradições perversas, nesse caso. Tudo se esclarecerá na continuação deste breve estudo.

Há, pelo Mundo afora, sinais de paternalismo9, moralismo e influência de ditames "religiosos" ou "pseudo-religiosos" (ou de ateísmo militante, mas com o mesmo tipo de

nos; e quem, de boa-fé, o defenda (em sentido semelhante aos que o negam) e alegue que a sua crítica é contra o diálogo. Ocorre o inverso: ele é que se investe da verdade única e excomunga e estigmatiza quem se lhe opuser. Poder-se-á vir a inventar outra designação, mas é a que corre. Cf. Beard e Cerf (1994); Estefanía (1998). E já o nosso (datado) Miragens do Direito. O Direito, as Instituições e o Politicamente Correto (CUNHA, 2003).

7 Muito especialmente no sentido cunhado por HAEBERLE (2003).

8 Pode ser ilustrativa e admonitória a leitura (com todos os cuidados) de Gui (2019).

9 Uma síntese da questão pode ver-se na dissertação de Ferraz Caldas (2003), tese de mestrado que tivemos a honra de orientar. 
discurso estigmatizador) em muitas propostas de alteração legislativa ou procedimentos de aplicação das leis. É preciso muita discussão pública, em um tempo lamentavelmente pouco apto a tal, pelo extremismo das posições, deficiente informação/documentação da maioria dos cidadãos, e muito pouca vontade de diálogo (por cansaço, falta de tempo, essa mesma falta de in-formação, e também porque os tempos andam para poucas conversas e mais para atitudes bruscas e de pretensa autoafirmação: alguns dogmas de "autoajuda" insistem em atitudes pouco conciliatórias). É necessário, antes de mais e acima de tudo, bom senso, em um momento de radicalização dos pontos de vista, e são necessárias formas ativas e eloquentes, persuasivas e não laxistas, de moderação, sob pena de o Direito passar a ser o braço armado de um particularismo punitivista qualquer: o que, em cada ordem jurídica, tenha tido mais fortuna. Ou simplesmente mais força.

Parecendo ser contraditório, mas absolutamente apenas complementar, se dirá que a Democracia não pode ser laxismo, nem-nem-ismo (BARTHES, 1978), frouxidão com condutas criminosas e antiéticas. Ou a Democracia encara que certas coisas são a sério, ou se prefere jogos florais e bizantinices, um dia acordará não acordando... Montesquieu sabia bem que a tirania começa com o sono, ou seja, o adormecimento das pedras vivas: "La servitude commence toujours par le sommeil. Mais un peuple qui n'a derepos dans aucun e situation, qui tâte sans cesse, \& trouve tous les endroits douloureux, ne pourroit guerres s'endomir." (MONTESQUIEU, 1748, p. 13).

\section{DIREITO, CIVILIZAÇÃO E MUDANÇA}

O Direito é, na Civilização, forma de regular uma ordem social considerada por um certo "consenso" político (o possível, em cada sociedade) como a mais adequada. E vão-se permanentemente fazendo ajustamentos, ultimamente com um certo frenesim ${ }^{10}$ de mudança legislativa, de criação de novas leis, que nem sempre passaram por crivo crítico, discussão pública e apuro técnico em diferentes países. Momento apressado e demagógico, o nosso! Momento por muitas razões, e mais por essa, muito perigoso.

Contudo, grandes mutações jurídicas ocorreram em tempo. Na sequência de mudanças constitucionais, normalmente após revoluções ou afins, era de se esperar que algumas alterações passassem das novas constituições para as leis ordinárias. Isso ocorreu em Portugal, por exemplo, muito provavelmente ainda não completamente em todos os domínios (mas globalmente sim), com a entrada em vigor da Constituição de 1976. E semelhantes processos foram ocorrendo noutros países que passaram por idênticas mutações constitucionais, as quais implicaram, naturalmente, alterações de legislação que ipso facto se tornaria inconstitucional. Figueiredo Dias lembrou algures que o Direito Penal terá sido dos primeiros ramos a constitucionalizar-se, em Portugal ${ }^{11}$.

10 Até no plano constitucional, em alguns países, e já há algum tempo. Veja-se também o que vai sucedendo no Brasil com um número pletórico de "emendas" constitucionais. Sobre a questão em Portugal, cf. Miranda (2001).

11 Com algumas atinências, cf. Ferreira da Cunha (1995); e o nosso livro A Constituição do Crime (CUNHA, 1998). 
Atualmente, a situação em que se vive, em vários países (perigosamente a aproximar-se de nós), é a de ruturas constitucionais mais ou menos inconstitucionais e um cair na rua da opinião jurídica. Os clamores de linchamento de certas personagens, nomeadamente políticos e outras figuras públicas, não conhece lei, culpa, ou prova, e o ódio é livremente apregoado. E leis, medidas e factos atropelam as Constituições. As redes sociais são muito culpadas nesses processos. Umberto Eco lançara um alerta: legiões de tontos agora têm voz igual à de um Prémio Nobel. Para não falar nas fake news, espelho popular da perigosíssima e destruidora "Pós-verdade", a que já muitos dão crédito e prestam veneração ${ }^{12}$... em uma notável flexibilidade antes o simples "estar-aí".

Ao mesmo tempo, diversos grupos, naturalmente com alguma razão quanto a passado e presente de não satisfação das suas reivindicações (umas serão direitos, outras meras aspirações...), procuram que novas leis os promovam, na verdade, assinalando fatores de preferência e, portanto, de desigualdade no balanço geral. Até que ponto a entorse agora operada compensa desequilíbrios passados é discutível. Contudo, o convívio com realidades práticas e o escândalo de desigualdades ainda vigentes leva a ultrapassar pruridos que pudesse haver com algum bem temperado uso de "quotas" que, em certos casos, são a única forma conhecida de ir invertendo um pouco ancestrais discriminações. Mas tudo tem de ser pensado com prudência.

Somos pessoalmente, na verdade, depois de muito ter pensado e de muitas situações de flagrante injustiça e impasse na sua solução por vias normais (como aflorámos, a ideologia da meritocracia é, em grande medida, e infelizmente, um discurso legitimador de desigualdades enraizadas e pétreas) a favor de bem ponderadas quotas para vários casos, nomeadamente de rendimento, raciais e de género, mas não cremos que algumas outras induzam qualquer benefício social geral ou sequer venham a compensar mesmo os respetivos grupos de supostas discriminações, ou mesmo de discriminações reais. Mesmo estas mais clássicas ações afirmativas são evidentemente perigosas e, no fim de contas, a sua adoção, no nosso caso, corresponde essencialmente à conclusão que se tornaram, no círculo fechado da distribuição dos choros e dos risos, como dizia Silva (1990), decerto a única forma não revolucionária, não de rutura, de compensar alguns grupos ancestralmente marginalizados. E que o continuam em geral a ser. Dir-se-á, então, tentando seguir uma moderada virtude da prudentia: mais valem quotas bem ponderadas que, a prazo, erupções de incontroladas revoltas, em que não haverá justiça, mas raiva e vingança - que terá a fundá-la uma perene e indiferente servidão. Mas, além desse argumento (apenas preventivo e de que se poderá duvidar seja muito bem-intencionado - embora no caso o seja), o maior é mesmo o da justiça dessa compensação: porque a desigualdade ou a servidão no passado não se quedaram na História, mas passam, como um pecado original, para o nosso tempo.

Problema, pois, não são as necessárias discriminações positivas mais clássicas, mas a sua extensão e abuso, em uma mentalidade que substitui a regra geral da igualdade entre todos e a competição pelo valor e pelos resultados por um simples paralelogramo de forças entre grupos, a ver qual o mais capaz de, pela pressão, conseguir mais vantagens para a sua "tribo".

12 Cf. Putnam (2008). 
Braço de ferro que, no limite, ronda a chantagem.

\section{PERIGO DO PUNITIVISMO POLITICAMENTE CORRETO}

Significativa é hoje a sanha punitivista. Todo o punitivismo é paranoico e desumano. A novidade é aquele pelo qual "novos inquisidores", arautos de novas verdades e vigilantes da "pureza”, procuram proibir e até criminalizar certos grupos e condutas: fumadores, quem use casacos de peles, gordos, "infoexcluídos", artistas, sedentários, consumidores de bebidas alcoólicas (ainda que moderadamente), estes são alguns dos alvos fáceis e em geral deveras indefesos contra essa maré de ataques de higienistas, puritanos e burocratas. Além de alguns ativistas quiméricos. E, assim, causas novas, nobres em si e na sua generalidade filosófica (como as da defesa dos animais), acabam por ser confundidas com "chinoiseries" e extremismos pelo cidadão comum a quem querem redefinir os padrões de vida: Brave new world! Não poderíamos mais chamar aos dicionários "pais dos burros": não por melindre da lexicografia, mas para não ferir Suas Excelências asininas? Se assim fosse, o ridículo não pagaria imposto.

Em alguns meios já há a tentação de que se obrigue a falar e escrever de forma politicamente correta. E o pior é que as regras vão-se complexificando cada vez mais, segundo as desinências que sempre haverá que introduzir na "novilíngua" (ORWELL, [19--?]). Por exemplo, fala-se em impor as palavras "bebeia” e "adolescenta”, ou então "camarado”. Dir-se-ia, pois: "bebés e bebeias", "adolescentes e adolescentas", "camaradas e camarados".

Noutros casos, quer-se censurar livros e filmes que não tenham veiculado uma certa ideia de "pureza" - desde logo, os clássicos. E se uns desejam impor a Bíblia nas escolas, cremos que mais por fetiche que realmente para a lerem e interpretarem (porque temos razões para não acreditar que consigam nem ler nem interpretar), outros a acham livro violento e imoral, impróprio para crianças e jovens: uma espécie de enciclopédia de todos os crimes e imoralidades.

Outros ainda avançam para proibir os professores de falar de "política" ("escola sem partido" - ignorando que a maior parte da política nem é partidária, e que é impossível, em algumas matérias, não falar de alguma política, ainda que historicamente). Também há quem advogue escola dita segura e sem novidades para os estudantes: não poderiam ser surpreendidos. E há movimentos antivacinação com consequências já dramáticas. Desde logo, entre os seus arautos, que morrem mesmo. E mais ainda os filhos.

O fumo, por exemplo, preocupa alguns tanto que o querem anunciar (prevenindo) antes de filmes, e outros mesmo banir os filmes (antigos, claro) em que se fume. Como pode haver um bom Western sem um solitário cowboy a fumar... e o índio e o seu cachimbo da paz?

Aliás, o desprezo pela qualidade da Arte (cinematográfica, pictórica, literária...) é absoluto. Parece encarar-se a Arte apenas como doutrinação, propaganda. E querer depurar-se completamente o que desagrada (a alguns), em nome de uma pretensa pureza que tudo passa à lupa e a fio de espada. Como se não pudesse haver obras de arte fumadoras, glutonas, alcoólicas e mesmo belicistas, racistas, sexistas, em que existam até crimes...

É acreditar muito pouco na compleição moral das pessoas comuns pensar que não 
resistirá a sua moral e a sua vontade à "exposição" a obras artísticas com "maus exemplos". O que aliás nem se verifica, porque os exemplos frequentemente são bons, apesar de pessoas míopes verem só maus exemplos. Como sublinharia a defesa de Madame Bovary. Apesar do comportamento de Ema Bovary, a célebre esposa do obscuro médico de província, o fim terrível que teve não poderá ser (inter alia) uma prova já de castigo e, portanto, de condenação por parte do autor? - é um pouco o que se deduz da encenação sobre o processo judicial assinada entre nós por Tiago Rodrigues. Não se pode confundir (de modo algum) a descrição do mal em uma obra de arte com a adesão a ele.

Os novos censores, ao aparentemente só deixarem passar obras "boazinhas", condenam a arte, em boa medida, à mais rasteira mediocridade. Será que Dostoievski estava certo ao afirmar que só há obra de arte com a contribuição do diabo?

Não é só no domínio da arte que a criminalização e a punição se agigantam.

Primeiro, eclodiu em Portugal a questão das toiradas. Depois, a diatribe contra provérbios e expressões que feririam os animais ou afins. $\mathrm{O}$ que virá depois? Tudo é possível. Quem pensaria que há responsáveis e governantes que acreditam e são militantes de fantasias contrárias aos dados da Ciência, que o Mundo foi criado em seis dias de calendário, que não existe aquecimento global, que o Holocausto nunca existiu?

Uma posição não radical poderá considerar que proibir entre nós as touradas seria, sem dúvida, um terrível golpe para alguns (chocaria aficionados e obviamente teria consequências económicas devastadoras para quem vive no âmbito dessa atividade), mas, em abstrato, constituiria ainda um progresso civilizacional, porque acabaria uma prática que não pode ser considerada hoje, essencialmente (por um observador estranho à "tradição"), arte, nem perícia, nem ritual, mas efetivamente uma banalização em espetáculo da tortura de um pobre animal. Embora, no caso dos forcados, haja um pouco mais de igualdade de armas, e em Portugal se não mate o toiro na arena, em geral, não são atenuantes de tomo. É tortura, sim. Socialmente aceite em grande medida, e, por isso, branqueada, e nem sequer apercebida como tal. Nisso (caso raro, nos tempos que correm), o politicamente correto tem alguma razão e está a dar um sinal ético-político positivo, embora certamente radical e fora do tempo ainda. Por outro lado, pergunta-se se não seria muito mais ajustada uma proibição administrativa, e não uma criminalização da conduta. Cremos que sim. Não se pode passar de oito a oitenta.

Entretanto, de forma alguma, poder-se-á enlamear o nome e queimar as obras de quem tenha posição diferente: Isso só dá razão a quem aponta os perigos de totalitarismo. Quem defende as touradas não é necessariamente uma pessoa má, insensível, ou bárbara. Há uma carga cultural a considerar. E aplica-se cabalmente aqui a conhecida frase de Walter Benjamin, para o qual todo o documento de cultura é também documento de barbárie. São essas subtilezas que escapam a alguns.

É certo que a nossa sociedade se encontra hoje muito retalhada, pulverizada, e é muito complicado ver consensos, tanto mais que há "microclimas" sociais e culturais (o caso das touradas é paradigmático - mesmo geograficamente se pode observar uma grande diferença de sensibilidade ao problema). Contudo, o Direito Penal necessita de colher não apenas a sua 
legitimação, mas a possibilidade prática até de, no limite, ser aplicado (falou-se, por exemplo, em inaplicação da lei em Barrancos por ação de moradores locais) da sua validação social.

Se os ânimos agitados que hoje prevalecem poderiam quiçá, em referendo, se o pudesse haver, votar pela pena de morte (o que seria, a nosso ver, um gravíssimo retrocesso ético), a verdade é que crimes quase se diria "naturais" (sabendo-se do risco dessa expressão e mesmo dessa ideia) são facilmente intuídos como tais pelas sociedades, enquanto a criminalização de certas condutas à mercê de razões ideológicas não é de forma alguma entendida (nem apoiada) pela generalidade dos cidadãos não ativistas e ideologizados nesse sentido. Ninguém achará (salvo alguém muito perturbado ou provocador) que o homicídio deva ser legalizado, para dar um único exemplo. E, na verdade, anda-se a múltiplas velocidades. Só recentemente (anuncia-se) teria o Senegal criminalizado o estupro... Nem nos parece que possa ser verdade...

Em todo aquele referido tipo de projetos criminalizadores, há de haver em grande atenção qual o fundamental bem jurídico ${ }^{13}$ tutelado. Fica-se em muitos casos com a impressão de que não se trata mesmo de um bem jurídico-penal, quer dizer, de um bem jurídico com uma alta conotação de desvalor socialmente reconhecido (reconhecido já, objeto de um consenso de reprovação, e acrescentaríamos: não bastando um consenso obtido por demagogia, mas consenso fundado em uma carga axiológica comprovada). Porque só essa alta reprovação social, aliada à seriedade e à gravidade da ofensa (desvalor imanente ou intrínseco, não meramente "sociológico"), constitui requisito bastante para o caráter verdadeiramente penal ou criminal do bem jurídico. Assim, admitem-se, obviamente outros bens jurídicos, ainda que não penais.

No caso, parece que se pretende pôr em ação o caráter pedagógico da lei antes de a reprovação social existir: criminalizar primeiro para obter depois o assentimento social. Por imitação, por respeito institucional, etc.. Ora esta é a típica forma de pensar e agir totalitária. Pensamos que alguma pedagogia jurídica poderá eventualmente aceitar-se, se benévola e algo inócua, em matérias mais anódinas (ou nas que representem defesa de uma Constituição democrática). Mas, no âmbito penal, é uma inversão do sentido normal das coisas, quase se diria, da sua natureza (natura rerum).

Geralmente, o politicamente correto tende para a ditadura de costumes, hábitos, comportamentos. Proibir-nos de dizer "pegar os toiros pelos cornos" é censurar a nossa expressão e um crime contra a cultura e a liberdade, que muito se manifestam na palavra sem peias ou mordaças. Devemos certamente ser tolerantes (aqui sim, se aplica com propriedade a expressão tolerância) (FARAGO, 2005) e não proibir as touradas, esperando que, pela educação, deixem de existir em um futuro não muito distante. Em nome da paz social, desde logo. Ao mesmo tempo, e com veemência, devemos bater-nos pela nossa liberdade de expressão. Um toiro sofre com bandarilhas, não sofre por o usarmos como metáfora. O que fere a "dignidade" de um burro se chamarmos a alguém "burro" por ser estúpido? Apenas se se acreditar que, no corpo de burro, está encerrada uma alma humana, como no Monstro e no sapo estão príncipes esperando por um beijo.

13 Cf., v.g., Prado (2014). 
A arte está também muito em perigo com a vaga de fundo puritana, a qual, para além profundamente desconhecedora da História e da Estética, quer proibir e punir o que se exibe sem qualquer pudor no Vaticano há séculos. Para não ir mais longe. Diz-se que (e ultimamente tem-se recordado) uma vez perguntado pelo escândalo de alguma ligeireza de vestes no calor do Brasil, Dom Hélder Câmara, que foi uma celebridade internacional na luta pelos Direitos Humanos nos tempos de chumbo, declarou preocupar-se mais com quem não tem que vestir...

Uns, para defender por vezes particularismos que não lembram ao diabo (ou talvez lembrem, porque ele é, etimologicamente, o que lança a confusão - diabolos), invocam progressismo e superior conceito ético, outras vezes corolários de abstratos conceitos ditos democráticos, em face da pretensa barbárie antiga; outros defendem qualquer barbaridade com o argumento da tradição: sim, a pena de morte, a tortura, a discriminação, tudo o que está antes do Iluminismo, da Revolução Francesa, da Modernidade e dos Direitos Humanos e da Democracia (que, ainda no séc. XVIII, era por muitos referida com ironia: foi esse o momento de viragem), tudo isso é muito mais "tradicional". De uma certa tradição... E o que de há duzentos anos para cá se foi (timidamente, em grande medida) instituindo é contrário a essa "tradição". Na verdade, já há muitos que desconhecem o que foram as grandes revoluções e mutações emancipatórias, e outros, delas tendo uma vaga ideia, são declaradamente contra. "Antigamente a vida era bela!" - acreditam, sem muito pensarem nisso.

Os extremismos particularistas e punitivistas e os retrógrados ou reacionários, naturalmente se dão (virtual ou realmente) as mãos, como gémeos inimigos. De um lado e de outro, de vez em quando, há um vislumbre de lucidez, porque compreendem a loucura de quem combatem. Mas não há nenhuma autorreflexão, muito menos autocrítica. $\mathrm{O}$ Bom senso e a paz social podem sucumbir à guerra de uns contra os outros.

Sublinhe-se, porém, que os reacionários, apostados em anular todas as conquistas da Modernidade (e muito especialmente do Iluminismo - desse Iluminismo que não foi Despotismo dito esclarecido), da Democracia, do Estado de Direito e, naturalmente, do Estado social (todos pilares da nossa Constituição), pretendem uma alteração global que afeta a ordem política das liberdades e dos direitos, pondo em risco todas as dimensões da vida de cada um.

Já os particularistas e punitivistas não recordamos que hajam posto em causa direta e explicitamente a ordem geral democrática, nem os direitos em geral: é antes uma revolução mental, moral e de costumes, ou seja, uma ditadura da vida civil, da cultura, do imaginário. E não está excluído que uns e outros se mesclem, confluem, se aliem. Na verdade, na medida em que os ditadores e candidatos a tal se misturam com movimentos donos da verdade, não apenas no plano histórico, como escatológico, está feito o casamento perfeito de controlo das consciências e das ações. É o fim do mundo - as we know it. E pode ser o apocalipse por que alguns tanto almejam, com guerras nucleares, regionais e mesmo mundiais, atiçadas pela loucura. É certamente um milagre se um voluntarista narcísico não irromper para um conflito armado.

Entretanto, caminha-se para uma sociedade fechada, barricada (em guerra civil) (ENZENSBERGER, 1993), e um Direito ao serviço de preconceitos ou de poderosos novos-ricos 
e da sua nula estética, de seitas mais ou menos fanatizantes, com desrespeito clamoroso pela liberdade, privacidade e outros direitos de muitos cidadãos, e, desde logo desprezo óbvio pela laicidade, ou de grupos ativistas, pseudo-avançados, que igualmente pregam novos dogmas, em geral higienistas, medicalistas, e não raro também de algum puritanismo.

Certamente chocados e aturdidos com essas situações, muitos moderados não encontraram ainda forças para sair do seu casulo e vir em defesa do bom senso e do bom gosto. Certamente alguns pensarão que se trata de modas passageiras, e outros não saberão mesmo como reagir. Alguns, porém, já entenderam que cavalgar a onda pode dar algum prestígio e mesmo proveito material, e naturalmente poder, pelo que hipocritamente aderem ou transigem com loucuras que colocam em risco liberdades antigas e modernas.

\section{NO FIO DA NAVALHA}

Há hoje clamores generalizados contra agressões ancestrais, que não eram muito faladas, e pouco chegariam a condenações na Justiça: muitos abusos contra a liberdade sexual, ataques a crianças e adolescentes, assédios de todo o tipo, designadamente no trabalho e na escola. E o assédio moral será o mais generalizado, e pouco denunciado, como sempre, pelo medo das represálias.

É positiva a denúncia, com é óbvio; porém, por vezes, ela fica pelo tom proclamatório, nem sempre rigoroso, eventualmente com generalizações que podem confundir ("tudo isto é aquilo”, ou isto é "null'altro che”, como detetou Lombardi Vallauri (1991)). Da agitação chocada e do disparar em todas as direções deveria passar-se à focalização e à prevenção. Nomeadamente a prevenção pela educação, pela família, escola e comunicação social. É preciso que as Democracias levem a sério a educação e a ética republicana, que invistam em cidadãos pensantes e não em votantes e consumidores amorfos ou carne para canhão de qualquer mobilização quando convenha.

No entanto, há mais Mundo! A vida normal e a sua eticidade simples deveriam ser mostradas como exemplo. Deprimem e assustam tanto delírio e ódio, sob capa de progresso ou de virtude. Por vezes virtude contra progresso, por vezes vice-versa, por vezes juntos, mas sempre ou quase discursos legitimadores. A Humanidade é bem melhor. O cidadão comum quer paz, não instigação às guerras, algumas de Alecrim e Manjerona. Porém, parece sentir-se que as sociedades se estão a transformar, com cada vez mais pessoas tristes, casmurras, irritadas (e irritadiças), egoístas, voluntaristas, totalmente desrespeitadoras de hierarquias (desde logo as do mérito; obedecendo à força apenas), cínicas, incapazes de reconhecer as virtudes e os valores, agressivas, arrivistas, pouco honestas, mal-educadas, insuscetíveis de dialogar, tudo justificando com uma liberdade de opinião que é, antes de mais, a prerrogativa de não pensar, não estudar, não conversar, não se retratar quando o erro é óbvio. Pior ainda é se, como alguns opinam, as massas sempre assim foram, só que agora as elites se estão a aperceber disso. Isso seria realmente terrível, não para a natureza humana (que, idealmente, se salvaria), mas para o grau de civilização em que nos encontramos. 
Nesse contexto, muitas das causas particularistas funcionam como uma alienação, desviando gente generosa e socialmente empenhada dos grandes desafios da defesa da Democracia e do Estado Social (e, naturalmente, de muitas outras atividades úteis e belas, nas Artes, nas Letras, nas Ciências...). Um dia poderão acordar sem liberdade de expressão e sem pensão de reforma, mas nem deram por nada no seu empenhamento contra as vacinas, os nus das estátuas dos museus, ou o ensino da filosofia e das ciências sociais nas escolas

\section{PROSPETIVA}

Ponderados todos esses séculos de dor geradora de dor, de miséria indutora de miséria, de vingança que engendra vingança, de ódio de base, de preconceito ancestral, renovado, de talião e retaliação, mas considerados também, por outro lado, os esforços de grandes humanitaristas penais de todos os tempos, e de muitas achegas renovadoras e reveladoras de juristas tout court, de filósofos, de sociólogos, de criminólogos, de políticos e outras pessoas de boa vontade, olhamos o futuro com Esperança,

Esperança que não prescinde de continuado labor.

Olhamos com Esperança os esforços de humanização e dignificação dessa área social e humana, outrora como que subtraída à própria sociedade e aos seus princípios, uma espécie de penumbra ou sombra do mundo, como alguém terá escrito já.

Vemos com esperança as tentativas várias e persistentes de um progresso de modernidade e civilização, de trazer luz a essas antigas trevas, pela moderação, pela ciência, pelo diálogo, pela conciliação, pela compreensão do Outro, que é, em geral, o grande problema, o grande obstáculo, o grande tabu.

Sem, obviamente, qualquer resvalar para um "desarmamento" do Estado e da sociedade em face a ofensas realmente graves e danosas, sem evidentemente qualquer laxismo, parece haver esperança em se ultrapassar coisas fora de época (embora haja ameaças de retorno, sobretudo por falta de educação), em que o bode expiatório era um instrumento ao mesmo tempo de controlo (e eventual eliminação) social de marginais e de submissão das massas que se deliciavam com o suplício dos apontados como culpados por todos os males...

Trata-se apenas de considerar sempre os envolvidos na relação jurídica penal (seria interessante desenvolver este conceito, de origem exógena à área, como é sabido), quaisquer que sejam, como pessoas, como seres que não perdem a sua dignidade, e como Homens e Mulheres devem ser tratados, ou seja, jamais como objetos ou coisas ou pretextos.

A Constitucionalização do Direito e do Processo Penais, cujas subtilezas e surpresas nunca certamente terminarão (como aliás em todo ou quase todo o Direito), requerendo sempre novas reformas humanizadoras e dignificadoras, é uma sólida esperança para futuro.

Por tudo isso, e porque os penalistas, da Academia e do Foro, assim como os Criminólogos, estão atentos e treinados em uma área particularmente interpelante que jamais os deixará adormecer, pode sonhar-se que um dia, em uma sociedade mais livre, mais justa e mais fraterna, para que justamente aponta a Constituição portuguesa, ou uma sociedade fraterna, pluralista 
e sem preconceitos, como bem diz a Constituição brasileira (mas outras o dizem com palavras idênticas) e especialmente mais educada e até por isso menos preconceituosa e agónica. E assim pode sonhar-se que essas questões passem, em boa parte, para a História do Direito. Nem todo o crime desaparecerá nem na mais perfeita das sociedades. Mas muito poderia evitar-se...

Para isso (para nos tornarmos também aqui o mais dispensáveis possível, evocando António Sérgio) vai trabalhando, pelo vasto mundo, e nas diferentes áreas jurídicas, o novo paradigma do Direito Fraterno Humanista, o qual, com vários nomes ou sem eles, vai fazendo o seu caminho.

Atrevemo-nos a conjeturar que terá sido graças a esse novo horizonte de pensamento que foi possível precisamente criar o Tribunal Penal Internacional e que um dia se porá em funcionamento o Tribunal Constitucional Internacional.

Entretanto, a Justiça chama por nós todos os dias, em qualquer lugar em que estejamos, em qualquer aqui e agora.

\section{REFERÊNCIAS}

BARTHES, Roland. Mythologies = Mitologias. Trad. portug. de José Augusto Seabra. Lisboa : Edições 70, 1978.

BEARD, Henri; CERF, Christopher. Dicionário do Politicamente correto. Trad. port. de Vera Karam e Sérgio Karam, Introdução de Moacyr Scliar. Porto Alegre: L\&PM, 1994.

CORREIA, Eduardo. Notas Críticas à Penalização das Actividades Económicas. In: CICLO de Estudos de Direito Penal Económico. Coimbra: Centro de Estudos Judiciários, 1985.

CORREIA, Eduardo et al. Ciclo de Estudos de Direito Penal Económico. Coimbra: Centro de Estudos Judiciários, 1985.

CUNHA, Paulo Ferreira da. A Constituição do Crime: da substancial constitucionalidade do direito penal. Coimbra: Coimbra Editora, 1998.

CUNHA, Paulo Ferreira da. Miragens do Direito. O Direito, as Instituições e o Politicamente Correto. Campinas: Millennium, 2003.

ENZENSBERGER, Hans Magnus. Aussichten auf den Buergerkrieg. Frankfurt: Suhrkampf, 1993.

ESTEFANÍA, Joaquín. Contra el Pensamiento único. 4. ed. Madrid: Taurus, 1998.

FARAGO, France. La Laïcité, tolérance voilée ? Nantes: Éditions Pleins Feux, 2005.

FERRAZ CALDAS, Ana. Paternalismo Jurídico: da proteção à intromissão (conceito, legitimidade e limite das medidas paternalistas. 2003. 76 f. Dissertação (Mestrado em Ciências Jurídico-Filosóficas) - Faculdade de Direito da Universidade do Porto, Porto, 2003. Dispo- 
nível em: https://repositorio-aberto.up.pt/handle/10216/66148. Acesso em: 15 ago. 2019. FERREIRA DA CUNHA, Maria da Conceição. Constituição e crime: uma perspectiva da criminalização e descriminalização. Porto: Universidade Católica Portuguesa Editora, 1995. FERRY, Luc. Apprendre à vivre. Traité de philosophie à l'usage des jeunes générations. Paris: Plon, 2006.

FERRY, Luc; CAPELIER, Claude. La plus belle histoire de la Philosophie. Paris: Robert Laffont, 2014.

GAUCHET, Marcel. Le désenchantement du monde. Paris: Gallimard, 1985.

GIANNETTI, Eduardo. Beliefs in action: Economic Philosophy and Social Changev = Mercado das Crenças. Filosofia Económica e Mudança Social. Trad. bras. de Laura Teixeira Motta. São Paulo: Companhia das Letras, 2003.

GUI, Bernardo. Il Manuale dell'Inquisitore. Introdução histórica de Marcello Simoni. Roma: Newton Compton, 2019.

HAEBERLE, Peter. El Estado Constitucional. Estudo introdutório de Diego Valadés. Trad. e índices de Héctor Fix-Fierro. México: Universidad Nacional Autónoma de México, 2003.

LOMBARDI VALLAURI, Luigi. Terre. Terra del Nulla. Terra degli Uomini. Terra dell'Oltre. Milano: Vita e Pensiero, 1991.

LYOTARD, Jean-François. A Condição Pós-Moderna. Tradução port. José Navarro. Revista e apresentada por José Bragança de Miranda. 2. ed. Lisboa: Gradiva, 1989.

LYOTARD, Jean-François. Réécrire la modernité: "cahiers de philosophie”. Lille: [s.n.], 19-.

MIRANDA, Jorge. Acabar com o Frenesim Constitucional. Separata do volume coletivo Nos 25 Anos da Constituição da República Portuguesa. Lisboa: Associação Académica da Faculdade de Direito de Lisboa, 2001.

MONTESQUIEU. De l'esprit des lois. [S.l.: s.n.], 1748.

ORWELL, George. 1984. Trad. port. Lisboa: Unibolso, [19--?].

PRADO, Luiz Regis. Bem Jurídico-Penal e Constituição. 7. ed. São Paulo: Editora Revista dos Tribunais, 2014.

PUTNAM, Hilary. O Colapso da Verdade e outros ensaios. trad. port. Aparecida, SP: Ideias \& Letras, 2008.

PUY, Francisco. Tópica Jurídica. Santiago de Compostela: Imprenta Paredes, 1984. 
PUY, Francisco. Derechos Humanos. Santiago de Compostela: Imprenta Paredes, 1985. v. 1. SILVA, Agostinho da. "A Justiça”. In: SILVA, Agostinho da. Diário de Alcestes. Lisboa: Ulmeiro, 1990.

TARDE, Gabriel de. Les Lois de l'imitation = As Leis da Imitação. Porto: Rés, 1976. 